\title{
Systematic psychiatric assessment of patients with sickle cell disease
}

Omar S. Al Zahrani, MD, Osama Mukhtar, MSc, Menahi Al Subaie, MD, Wazenah E. Al Howiti, Nur-Dip.

\section{ABSTRACT}

$$
\begin{aligned}
& \text { الأهداف : لتحد يد مستوى المشاكل النفسية مثل الاكتئاب والقلق }
\end{aligned}
$$

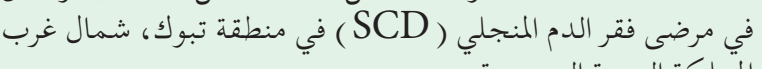

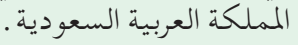

$$
\begin{aligned}
& \text { الطريقة : أجريت هذه الدراسة المستعرضة، تم تقييم } 89 \text { مريضا مع الحمار }
\end{aligned}
$$

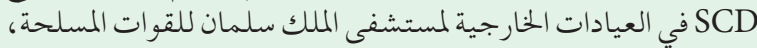

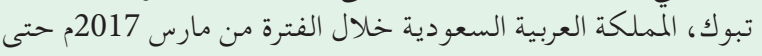

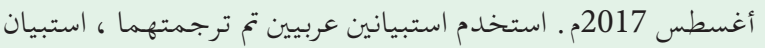

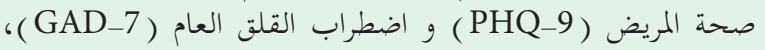

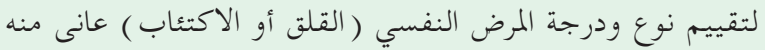

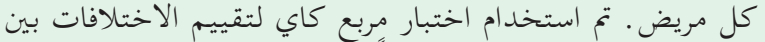

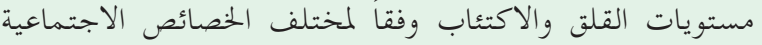

$$
\begin{aligned}
& \text { والديموغرافية للمشار كين. }
\end{aligned}
$$$$
\text { النتائج: حسبنا القيم عن طريق تحليل ألفا كرونباخ لاستبيانات }
$$

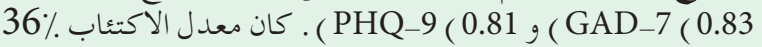

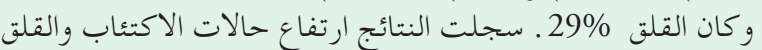

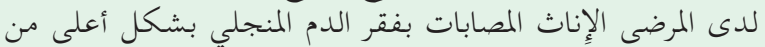$$
\text { الذكور ( }
$$

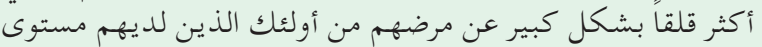

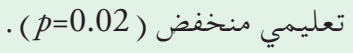

الخاتمة : أظهرت الدراسة أن العلاقة بين الاكتئاب والقلق فيما يتعلق

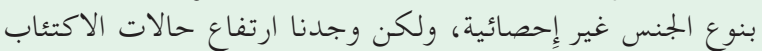

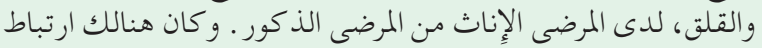

$$
\text { كبير مع القلق بين المرضى ذوي الإناث من المستوى المضى التعليم العالي . }
$$

Objectives: To determine the level of the psychological problems such as depression and anxiety in sickle cell disease (SCD) patients in Tabuk region, northwestern Saudi Arabia.

Methods: In this cross-sectional study, 89 patients with SCD was assessed in the outpatient clinics of King Salman Armed Forces Hospital, Tabuk, Saudi Arabia between March 2017 and
August 2017. Two validated Arabic translated questionnaires, the Patient Health Questionnaire (PHQ9) and the Generalized Anxiety Disorder (GAD-7), were used to assess the type and degree of psychopathology (anxiety or depression) each patient suffered. Chisquare test was used to assess the differences between anxiety and depression levels according to the different sociodemographic characteristics of the participants.

Results: The values were computed by analyzing the Cronbach's alphas for the GAD-7 (0.83) and PHQ-9 (0.81) questionnaires. The rate of depression was $36 \%$ and anxiety was $29 \%$. Female patients with SCD reported a higher incidence of depression and anxiety than males $(p>0.05)$. Patients with a higher level of education were significantly more anxious about their illness than those with a lower level education $(p=0.02)$.

Conclusion: A statistically insignificant association was reported between depression and anxiety with regard to gender; however, female patients reported a higher incidence of depression and anxiety than male patients. A significant association with anxiety was reported among patients with higher levels of education.

Saudi Med J 2019; Vol. 40 (1): 59-65

doi: 10.15537/smj.2019.1.22919

From the Prince Sultan Oncology Center (Al Zahrani, Mukhtar), Psychiatric Department (Menahi), and Health Education (Al Howiti), King Salman North West Armed Forces Hospital, Tabuk, Kingdom of Saudi Arabia.

Received 6th August 2018. Accepted 14th November 2018.

Address correspondence and reprint request to: Dr. Omar $S$. Al Zahrani, Prince Sultan Oncology Center, King Salman North West Armed Forces Hospital, Tabuk, Kingdom of Saudi Arabia. E-mail:psoc.research@gmail.com

ORCID ID: orcid.org/0000-0001-7344-1462 
Sickle cell disease (SCD) is due to the disorder in $\checkmark$ the blood hemoglobin. The disease indications are evident in the early age of the patient. ${ }^{1}$ In the SCD patients, the usual functioning of the blood cells is disturbed which results in the form of body fatigues and severe episodes of pain. These physical changes in the body become the cause of psychological disorders and depression, and anxiety are the most common among them. These psychosocial disorders have a negative impact on quality of life (QoL) to the patients. ${ }^{2}$ The World Health Organization (WHO) reported that depression affects over 154 million individuals globally. ${ }^{3}$

Symptoms of anxiety and depression are reported more often in females than males. ${ }^{4} \mathrm{~A}$ national-level survey conducted in Australia in 2008, reported 17.9\% females compared to $10.3 \%$ of males were experiencing depression. ${ }^{5}$ The prevalence of depression and anxiety in Latin America and the Caribbean is twice that of males in these regions. ${ }^{6}$ A survey carried out by the National Institute of Mental Health (NIMH) in the United States also found that females were more likely to experience depression than males. ${ }^{3}$ Females' education levels are more closely associated with the use of advanced health services than primary care. ${ }^{7}$ Females with a higher education level usually report to advanced health facilities with psychiatric support services rather than primary care facilities, which may explain the higher incidence of depression and anxiety. Societal attitudes and the impact of pain are the main reasons for psychological complications in SCD patients. The literature has reported a high prevalence of psychosocial disorders in patients with SCD in the west. ${ }^{8,9}$ The rates of depression in SCD patients (18\% to 46\%) were found to be very similar to those seen in other chronic diseases. ${ }^{9-12}$ Nevertheless, controlling for all other physically related illnesses, depression rates were found to be higher in SCD patients than that of the general population. ${ }^{9}$ A Pain in Sickle Cell Epidemiology Study (PiSCES) project found that $27 \%$ of adult SCD patients experienced depression and $6.5 \%$ had anxiety. ${ }^{8}$ Another PiSCES project reported that SCD patients who had depression and anxiety had poor QoL; it also found that they were frequently visiting hospital emergency services (ERs) and using opioids on a regular basis. ${ }^{9}$ Depression and anxiety not only have negative impact on the social life of the individual but

Disclosure. Authors have no conflict of interests, and the work was not supported or funded by any drug company. also place a heavy financial burden on the individual and community health services. Cost of treatment for a depressed patient is comparatively doubled than a normal patient. ${ }^{13}$ In a recent study, depression was found associated with the more usage of health care resources in the SCD patients. ${ }^{14}$ The psychological problems seen most often in SCD patients are anxiety, depression, aggression, and social withdrawal. ${ }^{15}$ There is a persistent negative perception of the use of opioid medications among SCD patients, which is believed to be the main cause of anxiety and depression in this cohort. Frequent emergency room (ER) visits, hospital admissions, SCD crises, and abrupt and chronic pain are all linked with the occurrence of depression in patients with SCD. ${ }^{8}$ An association between anxiety, poor QoL, and persistent pain was reported in SCD patients. ${ }^{8}$ The identification and treatment of psychological problems, especially depression and anxiety, is of paramount importance for SCD patients.

Our aim in this study is to find out the level or phase of the 2 psychological complications such as depression and anxiety among the patient of SCD in the northwestern region of Tabuk, Saudi Arabia.

Methods. This is a cross-sectional observational study. Patients with SCD followed in the outpatient clinics of King Salman Armed Forces Hospital in the north western region, Tabuk, Saudi Arabia between March 2017 and August 2017 were included in the study. Approval for the study was obtained from the Research Ethic Committee of the hospital. Only patients over 14 years of age were included in the study; SCD patients younger than 14 years old or diagnosed with an opioid use disorder were excluded. Those SCD patients who became addict to pain killer drugs up to a limit that leads to some serious damages are referred as opioid disorder. After a thorough psychiatric consultation, 21 opioid disorders were excluded from the study. Initially, 102 patients participated in the study, but 13 participants were dropped due to the information they provided being incomplete or refusing consent. The study included analyses of 89 patients with SCD followed at the Hemoglobinopathy and Pain Clinics. A Medical Services General Directorate (MSD) approved consent form was signed by each patient by himself, his legal guardian, or relative. Two validated Prime MD Patients Health questionnaires translated into Arabic were used to assess the type and degree of psychopathology (anxiety and/or depression) each patient suffered. The Patient Health Questionnaire (PHQ-9) (Appendix I) and Generalized Anxiety Disorder (GAD-7) questionnaire (Appendix II) were 
used to assess the patients' levels of depression and anxiety, and their respective Cronbach's alpha values were used to determine the internal reliability of the instruments. All data from these questionnaires were entered into Statistical Package for Social Sciences Version 21 (Armonk, NY: IBM Corp.). Descriptive analyses of the sociodemographic characteristics of the participants and their overall depression and anxiety levels are presented in tables and graphs. The $\chi^{2}$ test was used to assess the differences between anxiety and depression levels according to the different sociodemographic characteristics of the participants. $P<0.05$ were considered statistically significant.

Results. A total of 102 SCD patients were selected for the study. The questionnaires from 13 patients were excluded from the analysis because their sociodemographic information was missing. Of the remaining 89 participants, 44 were males and 45 were females. Fifty-four patients $(61 \%)$ had never been married, while $31(35 \%)$ were married, and 3 (3\%) were divorced. The median age of the sample population was 26.0 (14-41) years, and $73 \%$ were between 14 and 29 years of age. Approximately $80 \%$ of the participants were students or unemployed (the majority were women). Only $10 \%$ of the patients had a monthly household income of more than 3000 USD; $36 \%$ had an income between 1000 and 2000 USD per month. The majority (58\%) of the patients in the sample population lived in a rented accommodation. Seventy-nine percent of the patients had a family history of SCD. The patients' sociodemographic characteristics are illustrated in Table 1.

The values were computed by analyzing the Cronbach's alpha values for the GAD-7 (0.83) and PHQ-9 (0.81) questionnaires. These higher Cronbach's alpha values demonstrated that the Arabic translations of the GAD-7 and PHQ-9 questionnaires used have high internal consistency. Analysis of the PHQ-9 questionnaire revealed that $30 \%$ of the SCD patients had no depression and 34\% had only mild depression. Twenty-seven percent of the patients had moderate depression, while $9 \%$ had moderate to severe or severe depression. These results are illustrated in Figure 1.

The results of the GAD-7 questionnaire showed that $46 \%$ of the SCD patients did not experience any anxiety related to their disease. Twenty-nine percent of SCD patients had a mild degree of anxiety, $22 \%$ had a moderate degree of anxiety, and $7 \%$ had severe anxiety. These results are presented in Figure 2.

With further evaluation and statistical analysis, scores of $\leq 10$ on both the GAD-7 and PHQ-9
Table 1-Results of the sociodemographic characteristics of the participants.

\begin{tabular}{|c|c|c|}
\hline Characteristics & $\mathrm{n}$ & $(\%)$ \\
\hline \multicolumn{3}{|l|}{ Gender } \\
\hline Male & 44 & (49) \\
\hline Female & 45 & $(51)$ \\
\hline \multicolumn{3}{|l|}{ Age } \\
\hline $14-19$ years & 25 & (28) \\
\hline 20-24 years & 16 & (18) \\
\hline $25-29$ years & 24 & (27) \\
\hline $30-34$ years & 12 & (14) \\
\hline $35-39$ years & 9 & (10) \\
\hline Over 40 years & 3 & (3) \\
\hline \multicolumn{3}{|l|}{ Marital status } \\
\hline Single & 54 & (61) \\
\hline Married & 31 & $(35)$ \\
\hline Divorced & 3 & (3) \\
\hline \multicolumn{3}{|l|}{ Employment status } \\
\hline Military & 4 & $(5)$ \\
\hline Non-military & 14 & (16) \\
\hline Student & 33 & (37) \\
\hline Unemployed & 38 & (43) \\
\hline \multicolumn{3}{|l|}{ Residential status } \\
\hline Owner & 37 & (42) \\
\hline Renter & 52 & (58) \\
\hline \multicolumn{3}{|l|}{ Monthly household income } \\
\hline Less than 1000 USD & 28 & (31) \\
\hline 1000-2000 USD & 32 & (36) \\
\hline 2000-3000 USD & 20 & (22) \\
\hline More than 3000 USD & 9 & (10) \\
\hline \multicolumn{3}{|l|}{ Education } \\
\hline Primary level & 7 & (8) \\
\hline Intermediate level & 19 & (21) \\
\hline Secondary level & 32 & (36) \\
\hline Diploma & 13 & (15) \\
\hline College level & 18 & (20) \\
\hline \multicolumn{3}{|l|}{ Family history of SCD } \\
\hline Yes & 70 & (79) \\
\hline No & 19 & (21) \\
\hline Values are pre & ercer & tage, \\
\hline
\end{tabular}

questionnaires was taken as a cutoff value for anxiety and depression. ${ }^{16,17}$ Among the sample of SCD patients, the rate of depression was $36.0 \%$ and the rate of anxiety was $29.2 \%$. Chi-square and Fisher's exact tests were applied to identify any difference between these psychological complications in SCD patients in different sociodemographic categories. The rate of depression in females $(56 \%)$ was higher than that of males (44\%), but the difference was not statistically significant $(p>0.05)$. Similarly, female SCD patients (58\%) were found to have higher levels of anxiety than males $(42 \%, p>0.05)$. There was no statistically significant difference in the depression and anxiety levels affecting the different age 
Table 2 - Statistics and $p=$ values of the inferential statistical analysis of depression and anxiety levels with different sociodemographic variables.

\begin{tabular}{|c|c|c|c|c|c|c|}
\hline \multirow[t]{2}{*}{ Characteristics } & \multicolumn{2}{|c|}{ Depression } & \multirow[t]{2}{*}{$P=$ value } & \multicolumn{2}{|c|}{ Anxiety } & \multirow[t]{2}{*}{$P=$ value } \\
\hline & & (\%) & & & $(\%)$ & \\
\hline Gender & & & 0.42 & & & 0.39 \\
\hline Male & 14 & (32) & & 11 & (25) & \\
\hline Female & 18 & (40) & & 15 & (33) & \\
\hline Age group & & & 0.33 & & & 0.39 \\
\hline 14-19 years & 8 & (32) & & 7 & (28) & \\
\hline 20-24 years & 5 & (31) & & 3 & (19) & \\
\hline $25-29$ years & 9 & (38) & & 7 & (29) & \\
\hline $30-34$ years & 4 & (33) & & 4 & (33) & \\
\hline 35-39 years & 6 & (67) & & 5 & (56) & \\
\hline Over 40 years & 0 & $(0)$ & & 0 & $(0)$ & \\
\hline Marital status & & & 0.45 & & & 0.24 \\
\hline Single & 17 & (31) & & 14 & (26) & \\
\hline Married & 14 & (45) & & 12 & (39) & \\
\hline Divorced & 1 & (33) & & 0 & $(0)$ & \\
\hline Employment status & & & 0.05 & & & 0.68 \\
\hline Military & 4 & (100) & & 1 & (25) & \\
\hline Non-military & 5 & (36) & & 6 & (43) & \\
\hline Student & 11 & (33) & & 9 & (27) & \\
\hline Unemployed & 12 & $(32)$ & & 10 & (26) & \\
\hline Residential Status Income & & & 0.55 & & & 0.93 \\
\hline Owner & 12 & $(32)$ & & 11 & (30) & \\
\hline Renter & 20 & (38) & & 15 & $(29)$ & \\
\hline Monthly household & & & 0.57 & & & 0.59 \\
\hline Less than 1000 USD & 13 & (46) & & 6 & (21) & \\
\hline 1000-2000 USD & 10 & (31) & & 10 & $(31)$ & \\
\hline 2000-3000 USD & 6 & (30) & & 6 & (30) & \\
\hline More than 3000 USD & 3 & (33) & & 4 & $(44)$ & \\
\hline Education & & & 0.12 & & & 0.01 \\
\hline Primary level & 1 & (14) & & 1 & (14) & \\
\hline Intermediate level & 4 & (21) & & 3 & (16) & \\
\hline Secondary level & 15 & $(47)$ & & 14 & $(44)$ & \\
\hline Diploma & 3 & (23) & & 0 & $(0)$ & \\
\hline College level & 9 & (50) & & 8 & $(44)$ & \\
\hline Family history of SCD & & & 0.32 & & & 0.75 \\
\hline Yes & 27 & (39) & & 21 & $(30)$ & \\
\hline No & 5 & $(26)$ & & 5 & (26) & \\
\hline
\end{tabular}

groups of SCD patients $(p>0.05)$. In terms of marital status, patients who were single were found to have slightly higher levels of depression than others, but the difference was not statistically significant $(p>0.05)$. Students and unemployed SCD patients were found to be more depressed than those who were employed $(p>0.05)$. There was no statistical difference in the depression and anxiety scores of patients with different incomes and residential status $(p>0.05)$.

Sickle cell disease patients with higher education levels were found to be more anxious about their disease $(p<0.05)$. The anxiety levels of the patients with secondary or college education were found to be statistically higher than those with lower education levels. Patients with a family history of SCD were found to be more depressed and anxious than those without a family history of SCD, although this difference was not statistically significant $(p>0.05)$. The results of the inferential statistical analysis are presented in Table 2.

Discussion. The objective of this cross-sectional observational study is to assess the level (severity) of psychological complications depression and anxiety in patients with SCD. The research was carried out at King Salman Armed Forces Hospital, Tabuk, Saudi Arabia. By assessing the level of psychological complications, medical professionals and caregivers will be able to offer further support and more effective treatment to 


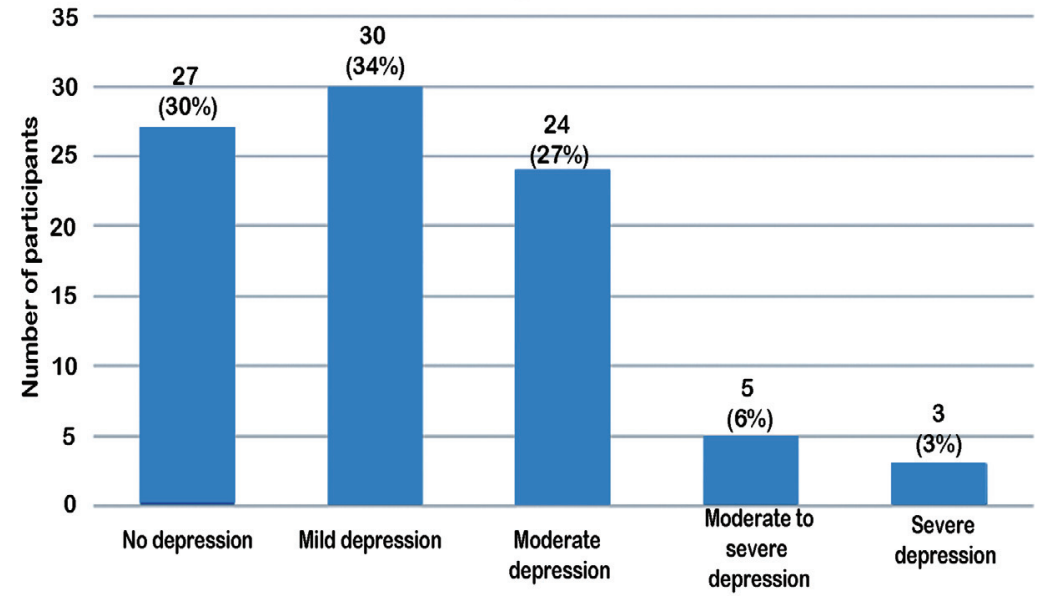

Figure 1 - Frequency and degree of depression in sickle cell disease patients.

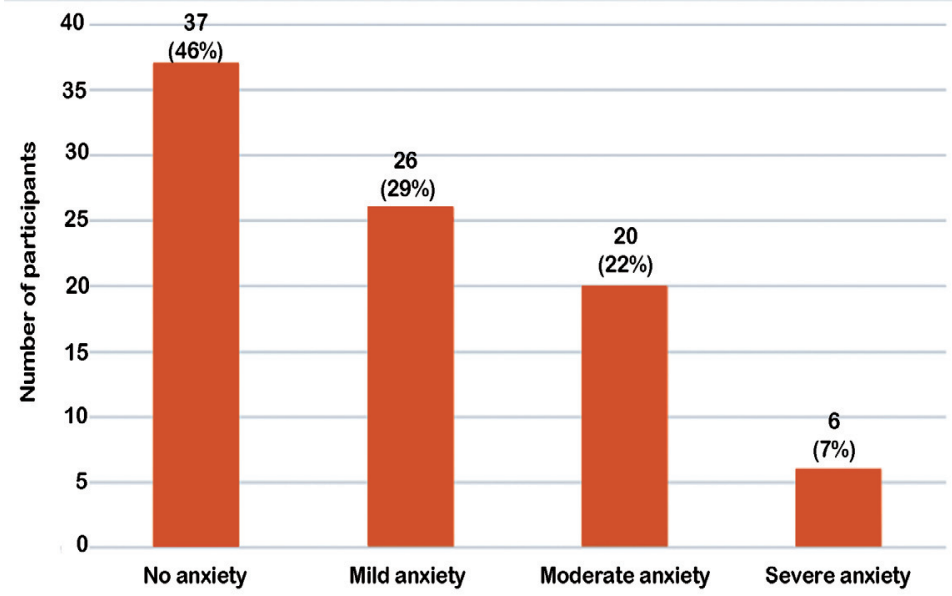

Figure 2 - Frequency and degree of anxiety in sickle cell disease patients.

these patients to improve their QoL. In the study, the rates of depression and anxiety identified among the sample population were $36 \%$ and $29 \%$ respectively. These results are comparable with those reported for depression and anxiety in patients with SCD in the literature. ${ }^{8,11,12}$ A higher rate of depression (28\%) was reported in African-Americans. ${ }^{8} \mathrm{~A}$ depression rate of $48.2 \%$ was reported among the SCD patients in Qitaf, Eastern province of Saudi Arabia. ${ }^{18}$ The anxiety rate of our study is comparable with the findings of Levenson et al. ${ }^{8}$ The rate of anxiety in our study is higher than that reported by Amin et $\mathrm{al}^{19}$ and Monroe et al. ${ }^{20}$ The difference in these levels of anxiety may be due to the sociocultural differences between the populations assessed in these studies. In our results, a slightly higher rate of depression and anxiety was reported in females than males $(p>0.05)$. Similarly, statistically insignificant higher rates of depression and anxiety were reported by Amin et $\mathrm{al}^{19}$ in their study on psychological symptoms among SCD patients in Ghana. However, these results failed to indicate any statistical significance of depression and anxiety scores when compared with different age groups. On the other hand, Adzika et $\mathrm{al}^{21}$ reported significantly higher depression scores in the 40 to 49-year-old age group compared to the other age groups. This may be explained by the fact that the majority of our sample population was younger, only $3 \%$ of the SCD patients we studied were 40 years of age or older. Regarding marital status, the majority of the SCD patients in our study were single, which is comparable with the previous findings. ${ }^{8}$ Married patients usually get more support and help from 
their counterparts during the course of their illness. However, single individuals lacked this support and compassion. Moreover, single SCD patients were found to be more hesitant to get married due to their illness. A higher percentage of patients in this category reported giving up their plans to marry. ${ }^{22}$ However, there was no significant difference in anxiety and depression scores among SCD patients and marital status, which was similar to the results published by Adzika et al. ${ }^{21}$ Regarding the education level of SCD patients, the data revealed a statistically significant association between anxiety scores and level of education. Patients with a higher level of education were found to be more anxious about their illness. The results are comparable with the finding of Suhaila et al. in their study of prevalence of mental disorders in adult population attending primary health care setting in Qatari population..$^{23}$ Although depression scores were also found to be higher among patients with secondary and college education, this difference was statistically insignificant. The higher depression and anxiety scores in patients with higher levels of education may be due to their prior awareness about the QoL and life expectancy of SCD patients. The findings of our study contradict those reported by Adzika et $\mathrm{al}^{24}$ who found a significant difference when comparing depression scores and level of education, although they failed to demonstrate any relationship between anxiety scores and level of education. As far as the family history of SCD patients is concerned, those who had a positive family history of SCD were found to be more depressed and anxious than those who did not $(p>0.05)$. This may be due to the fact that these patients already have at least one family member with the same illness, which can have a spontaneous negative psychological impact on the patient. Similar findings were reported in a previous study on family history of SCD and psychological problems. ${ }^{24}$

Study limitations. This is a time based study. Collected the data on convenience based sampling with in a period of 6 months of the study. Further studies with larger sample size is recommended for more statistically significant results.

In conclusion, the higher Cronbach's alpha values for the Arabic translations of the GAD-7 and PHQ-9 questionnaires demonstrated their high internal consistency. Anxiety was seen in $29 \%$ of the sample population and depression in $36 \%$. No significant relationship was reported between the level of depression and anxiety with regard to gender, age, marital status, income, or place of residence. Female patients reported higher incidences of depression and anxiety than their male counterparts. A significant association of anxiety with higher levels of education was reported. However, a larger number of patients and a longer period of follow-up are still needed to draw more definite and final conclusions.

\section{References}

1. US National Library of Medicine. Sickle cell disease 2018. [Accessed 2018 November 3]. Available from: https:/ghr.nlm. nih.gov/condition/sickle-cell-disease\#definition

2. Toumi ML, Merzoug S, Boulassel MR. Does sickle cell disease have a psychosomatic component? A particular focus on anxiety and depression. Life Sciences 2018; Aug: 29.

3. National Institute of Mental Health. Major depressive disorder among adults. [Accessed 2017 December 2017]. Available from: https://www.nimh.nih.gov/health/statistics/major-depression. shtml

4. Women and mental health. Geneva $(\mathrm{CH})$ : World Health Organization; 2010.

5. National survey of mental health and wellbeing: summary of results 2007. Canberra (AUS): Australian Bureau of Statistics; 2008.

6. Gaviria SL, Rondon MB. Some considerations of women's mental health in Latin American and the Caribbean. Int Rev Psychiatry 2010; 22: 363-369.

7. Stewart DE, Dorado LM, Diaz-Granados, Rondon M, Saavedra J, Posada-Villa J, et al. Examining gender equity in health policies in low-(Peru), middle-(Colombia), and high-(Canada) income country in the Americas. J Public Health Policy 2009; 30: 434-454.

8. Levenson JL, McClish DK, Dahman BA, de A Citero V, Penberthy LT, Aisiku IP, et al. Depression and anxiety in adults with sickle cell disease: the PiSCES project. Psychosom Med 2008; 70: 192-196.

9. Levenson JL. Psychiatric issues in adults with sickle cell disease. Primary psychiatry. [Updated 2008 May 1; Accessed 2017 December 19]. Available from: http://primarypsychiatry.com/ psychiatric-issues-in-adults-with-sickle-cell-disease/

10. Adam SS, Flahiff CM, Kamble S, Telen MJ, Reed SD, De Castro LM. Depression, quality of life, and medical resource utilization in sickle cell disease. Blood Advances 2017; 1: 1983-1992.

11. Edwards CL, Green M, Wellington CC, Muhammad M, Wood M, Feliu M, et al. Depression, suicidal ideation, and attempts in black patients with sickle cell disease. J Natl Med Assoc 2009; 101: 1090-1095.

12. Jerrell JM, Tripathi A, McIntyre RS. Prevalence and treatment of depression in children and adolescents with sickle cell disease: a retrospective cohort study. The primary care companion to CNS Disorders 2011; 13: (2).

13. Kauf TL, Coates TD, Huazhi L, Mody-Patel N, Hartzema AG. The cost of health care for children and adults with sickle cell disease. Am J Hematol 2009; 84: 323-327.

14. Jonassaint CR, Jones VL, Leong S, Frierson GM. A systematic review of the association between depression and health care utilization in children and adults with sickle cell disease. $\mathrm{Br} \mathrm{J}$ Haematol 2016; 174: 136-147.

15. Anie KA, Green J. Psychological therapies for sickle cell disease and pain. Cochrane database systematic reviews. [Updated 2012 February 15; Accessed 2017 December 20]. Available from: http://cochranelibrary-wiley.com/doi/10.1002/14651858. CD001916.pub2/full 
16. Manea L, Gilbody S, McMillan D. Optimal cut-off score for diagnosing depression with the Patient Health Questionnaire (PHQ-9): a meta-analysis. CMAJ 2012; 184: E191-E196.

17. Spitzer RL, Kroenke K, Williams JB, Löwe B. A brief measure for assessing generalized anxiety disorder: the GAD-7. Arch Intern Med 2006; 166: 1092-1097.

18. Alhomoud MA, Gosadi IM, Wahbi HA. Depression among sickle cell anemia patients in the eastern province of Saudi Arabia. Saudi J Medicine and Medical Sciences 2018; 6: 8-12

19. Amin MT, Osafo J, Yirdong F. Prevalence of psychological symptoms among adults with sickle cell disease in Korle-Bu Teaching Hospital, Ghana. BMC Psychology 2016; 4: 53.

20. Monroe CE, Affuso O, Martin MY, Aung M, Crossman L, Jolly PE. Correlates of symptoms of depression and anxiety among clinic outpatients in western Jamaica. West Indian Med J 2013; 62: 533-542.
21. Adzika VA, Glozah FA, Aboagye AD, Ahorlu CSK. Sociodemographic characteristics and psychosocial consequences of sickle cell disease: the case of patients in a public hospital in Ghana. J Health Popul Nutr 2017; 36: 4.

22. Al Sulaiman A, Suliman A, Al Mishari M, Al Sawadi A, Owaidah TM. Knowledge and attitude toward the hemoglobinopathies premarital screening program in Saudi Arabia: populationbased survey. Hemoglobin 2008; 32: 531-538.

23. Ghuloum S, Bener A, Abou-Saleh MT. Prevalence of mental disorders in adult population attending primary health care setting in Qatari population. JPMA Journal of the Pakistan Medical Association 2011; 61: 216-221.

24. McLaughlin KA, Behar E, Borkovec TD. Family history of psychological problems in generalized anxiety disorder. J Clin Psychol 2008; 64: 905-918. 